\title{
A new psammophilic species of the catfish genus Ammoglanis (Siluriformes, Trichomycteridae) from the Amazon River basin, northern Brazil
}

\author{
Elisabeth Henschel ${ }^{1}$, Pedro H.N. Bragança ${ }^{2}$, Filipe Rangel-Pereira ${ }^{1}$, Wilson J.E.M. Costa ${ }^{1}$ \\ 1 Laboratory of Systematics and Evolution of Teleost Fishes, Institute of Biology, Federal University of Rio de Janeiro. Avenida Carlos Chagas \\ Filho 373, Caixa Postal 68049, CEP 21941-971, Rio de Janeiro, Rio de Janeiro, Brazil \\ 2 South African Institute for Aquatic Biodiversity, Private Bag 1015, Grahamstown 6140 South Africa
}

http://zoobank.org/ABA3C83D-4EC8-4F8B-94D3-BE153BB03FA5

Corresponding author: Elisabeth Henschel (elisabeth.henschel@hotmail.com)

Academic editor: Nicolas Hubert • Received 30 November 2019 • Accepted 4 February 2020 • Published 18 February 2020

\begin{abstract}
Ammoglanis obliquus sp. nov., a minute catfish species reaching a maximum adult size of $15.5 \mathrm{~mm}$, is described from the Rio Preto da Eva drainage in the central Brazilian Amazon. It is distinguished from all of its congeners in possessing an exclusive combination of character states, including the presence and number of premaxillary and dentary teeth, number of interopercular and opercular odontodes, presence of cranial fontanel, number of dorsal-fin rays, number of anal-fin rays, number of caudal-fin rays, number of pelvic-fin rays, number of pectoral-fin rays, absence of pelvic splint, antorbital morphology, and absence of supraorbital and autopalatine morphology. It is considered to be a member of a clade also including A. pulex and A. amapaensis due to the unique oral, antorbital, and autopalatine morphology. Ammoglanis obliquus is regarded as more closely related to A. pulex than to any other congener, as both species exhibit a similar colour pattern, an absence of the metapterygoid, and the presence of two finger-like projections on the chin region.
\end{abstract}

\section{Key Words}

Taxonomy, tropical rain forest, Sarcoglanidinae, systematics

\section{Introduction}

The Amazon river basin exhibits the greatest diversity of fish species in the world, harbouring more than 2,400 species (Reis et al. 2016). Among this diversity, 956 species are representatives of the order Siluriformes (Dagosta and de Pinna 2019), popularly known as catfishes. Occupying a wide range of habitats throughout this basin (e.g. lakes, streams, waterfalls, rapids, and flooded forests; Aedriens et al. 2010), catfishes are known for their adaptability, but their presence in sandbanks highlights how specialized these fishes can be. Despite being widespread and structurally simple, sand bottom habitats shelter a unique fish fauna that bears some remarkable morphological features: cryptic colour (usually translucent or light-coloured body), small body size, eyes dorsally placed (sometimes reduced or absent), and a specialized head morphology (Zuanon et al. 2006). These characteristics can be found in several sand-dwelling (i.e. psammophilic) lineages of the family Trichomycteridae, such as the subfamily Sarcoglanidinae.

Members of Sarcoglanidinae are exclusively psammophilic, inhabiting loose patches of sand in both clearwater (Costa 1994; Zuanon and Sazima 2004) and blackwater streams (de Pinna and Winemiller 2000; Costa et al. 2019). They are miniaturized catfishes that do not exceed $25 \mathrm{~mm}$ of standard length (de Pinna 1989) and are generally translucent, which allows for camouflage with the surrounding environment (Myers and Weitzman 1966; de Pinna 1989; Costa 1994). Their association with 
sandy-bottom habitats is so strong that sarcoglanidines bury themselves in the sand when disturbed and when resting (Zuanon and Sazima 2004; Zuanon et al. 2006), to the extreme that Ammoglanis pulex de Pinna \& Winemiller, 2000 burrows $20 \mathrm{~cm}$ deep into the substrate (de Pinna and Winemiller 2000).

Sarcoglanidinae was erected by Myers and Weitzman (1966) to allocate at that time two new distinct genera and species, Sarcoglanis simplex Myers \& Weitzman, 1966 and Malacoglanis gelatinosus Myers \& Weitzman, 1966. Few morphological characters (Myers and Weitzman 1966; de Pinna 1989; de Pinna and Starnes 1990; Costa 1994; de Pinna and Winemiller 2000) have been described to diagnose Sarcoglanidinae and its genera. However, a recent molecular analysis directed to establish relationships of interstitial trichomycterids from the Atlantic Forest indicated that Sarcoglanidinae, in the sense of previous studies, is a polyphyletic assemblage comprising unrelated lineages with convergent morphological adaptations to the psammophilic life-style (Costa et al. 2020). Currently, according to Costa et al. (2020), Sarcoglanidinae comprises five genera: Malacoglanis Myers \& Weitzman, 1966, Sarcoglanis Myers \& Weitzman, 1966, Stauroglanis de Pinna, 1989, Stenolicmus de Pinna \& Starnes, 1990, and Ammoglanis Costa, 1994.

Ammoglanis was considered to be exclusively Amazonian, but recently, A. multidentatus Costa, Mattos \& Santos, 2019 was described from northeastern Brazil, which expanded the geographical range of Ammoglanis 1000 $\mathrm{km}$ to the east (Costa et al. 2019). Three other species are currently recognized for the genus: Ammoglanis diaphanus Costa, 1994, from the Araguaia river basin; A. pulex from the Orinoco river basin; and Ammoglanis amapaensis Mattos, Costa \& Gama, 2008 from the Jari river ba$\sin$. The recent description of $A$. multidentatus illustrates that undocumented species may occur throughout South America (Costa et al. 2019). The current paper contributes to elucidating the species diversity of sarcoglanidines by describing a new species of Ammoglanis from the Amazon river basin, northern Brazil.

\section{Material and methods}

Collections were made with a permit provided by Instituto Chico Mendes de Conservação da Biodiversidade as approved by Instituto Chico Mendes de Conservação da Biodiversidade (ICMBio; permit number 54636-3). Specimens were captured with small dip nets and euthanized in a buffered solution of ethyl-3-amino-benzoat-methanesulfonate (MS-222) at a concentration of 250 $\mathrm{mg} / \mathrm{l}$ until completely ceasing opercular movements, according to animal welfare laws and guidelines (Leary et al. 2013; Close et al. 1996, 1997). Morphological characters were obtained from specimens fixed in formalin for a period of 10 days and then transferred to $70 \%$ ethanol. Specimens are deposited in the ichthyological collection of the Instituto de Biologia, Universidade Federal do Rio de Janeiro, Rio de Janeiro (UFRJ). Comparative material is listed by Costa (1994), Mattos et al. (2008), and Costa et al. (2019). Additional comparative material is listed in Supplementary file 1. Measurements and counts follow Costa (1992), with the addition of preanal length (measured from snout tip to origin of anal fin), first pectoral-fin ray length (measured from basis of first-pectoral fin to its tip), and opercular patch length (longitudinal length of the opercular patch of odontodes). Measurements are presented as percentages of standard length (SL), except for those related to head morphology, which are expressed as percentages of head length. Cleared and stained (CS) specimens for osteological examination were prepared according to Taylor and Van Dyke (1985). Osteological nomenclature follows Datovo and Bockmann (2010). Osteological illustrations were made using a stereomicroscope Zeiss Stemi SV 6 with a camera lucida. Fin-ray counts include all elements, and vertebral counts include all vertebrae except those part in the Weberian apparatus; the compound caudal centrum was counted as a single element. Roman numerals represent unbranched rays and Arabic numerals represent branched rays in each fin-ray count. In the description, the frequency of each fin-ray count is given in parentheses after each count.

\section{Results}

\section{Ammoglanis obliquus sp. nov.}

http://zoobank.org/64D9D3EB-AB94-4AB8-9672-F5DD235DD017 Fig. 1A, B, 2, Table 1

Holotype. UFRJ 12477, 14.1 mm SL; Brazil: Amazonas state: Rio Preto da Eva municipality: sandbank at small stream, Preto da Eva River drainage, Amazonas river basin, 02 $46^{\prime} 27^{\prime \prime S}$, 59 $38^{\prime} 58^{\prime \prime} \mathrm{W}$, altitude about $20 \mathrm{~m}$ a.s.l.; collected by E. Henschel, P. Bragança and F. Rangel-Pereira, 28 August 2019.

Paratypes. UFRJ 12448, 25, 12.0-15.5 mm SL; UFRJ 12479, 4, 12.8-13.2 mm SL; UFRJ 12478, 4 (CS), 13.0$14.1 \mathrm{~mm}$ SL; INPA 59277, 2, 12.8-12.9 mm SL; all collected with holotype.

Diagnosis. Ammoglanis obliquus differs from all its congeners except $A$. pulex by the presence of seven diagonal rows of dark cromatophores forming a banded pattern on flank of live specimens (vs trunk with three longitudinal rows of dark chromatophores in A. diaphanus and A. amapaensis, or whitish with few minute dark chromatophores scattered on body in A. multidentatus), the absence of metapterygoid (Fig. 3; vs presence), and by the presence of two finger-like projections on chin region (de Pinna and Winemiller 2000: fig. 2b; vs absence). It is distinguished from $A$. pulex by the presence of dentary teeth (Fig. 4A; vs absence), the presence of premaxillary teeth (Fig. 4B; vs absence), by having $6+6$ caudal-fin rays (vs $5+5$ ), and by the absence of the pelvic splint (vs presence). It further differs from A. diaphanus, 


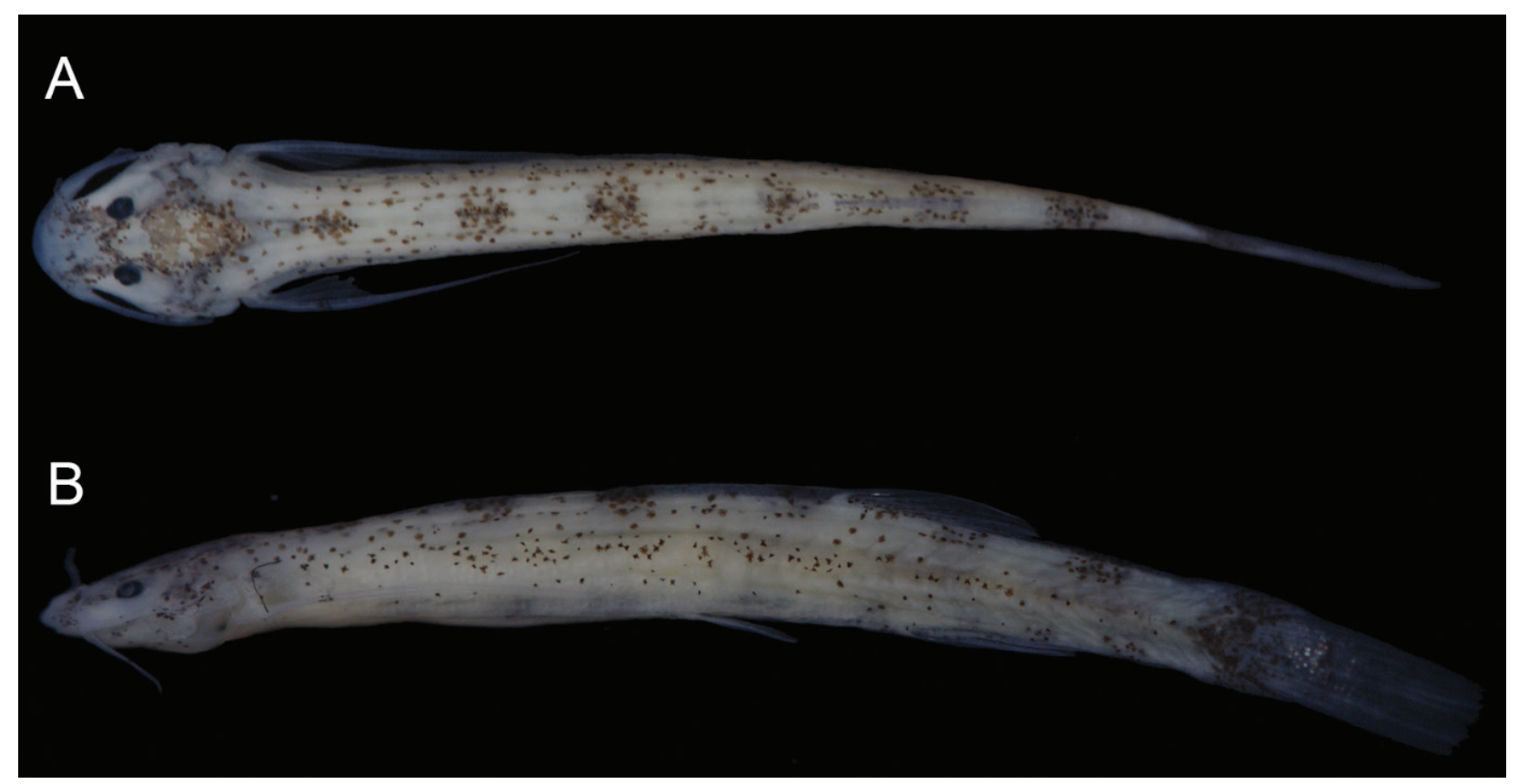

Figure 1. Ammoglanis obliquus: UFRJ 12477, $14.1 \mathrm{~mm}$ SL (holotype): Amazonas river basin. A. Lateral left view; B. Dorsal view.

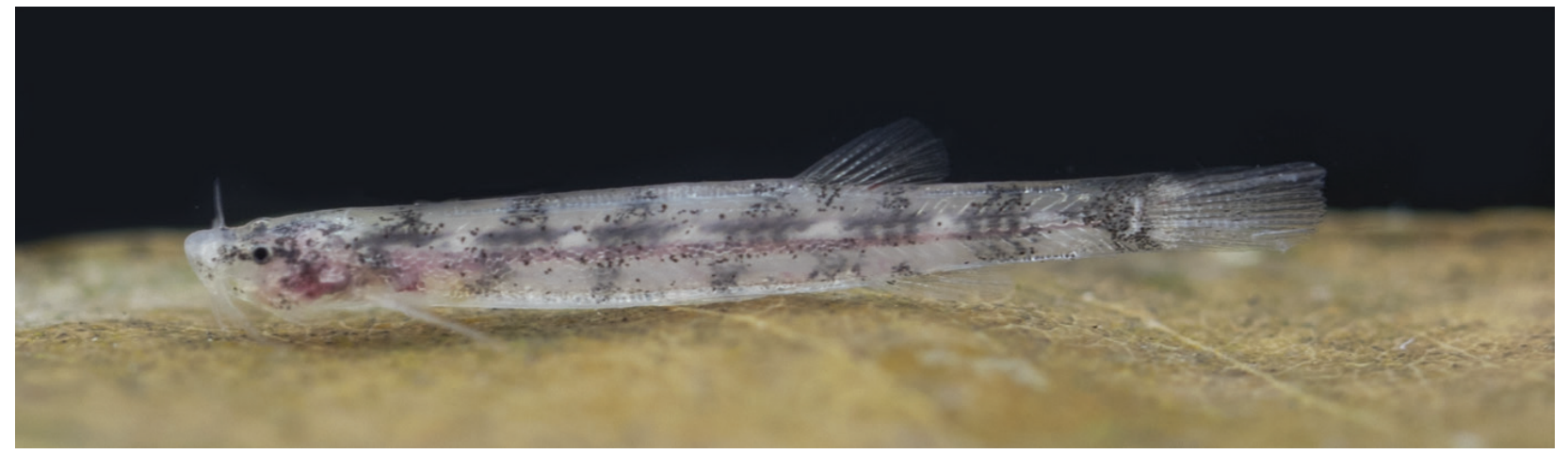

Figure 2. Live specimen of Ammoglanis obliquus: UFRJ 12448; $13.0 \mathrm{~mm}$ SL.

A. amapaensis, and $A$. multidentatus by the absence of the sesamoid supraorbital (Fig. 5, vs presence), by having fewer premaxillary teeth ( 3 vs 9-12 in A. diaphanus, 8-11 in A. amapaensis, and 10 or 11 in A. multidentatus), fewer dentary teeth (4 vs 8 in $A$. diaphanus, 7 or 8 in A. amapaensis, and 11-13 in A. multidentatus), and fewer dorsal-fin rays (total of $8 v s 10$ in A. diaphanus, 9 in $A$. amapaensis, and $A$. multidentatus). It is distinguished from $A$. diaphanus and $A$. multidentatus by the presence of 6 pectoral-fin rays (vs 7 in A. diaphanus and 7 or 8 in $A$. multidentatus), and the presence of a scythe-shaped antorbital (vs antorbital straight, with its tip not curved mesially); from $A$. amapaensis, by the presence of a wide cranial fontanel (vs dorsal surface of the neurocranium totally ossified, without a fontanel; Mattos et al. 2008: fig. 4), absence of separate ossification of the anterior cartilage of autopalatine (vs presence); from $A$. multidentatus, by possessing fewer opercular odontodes (8-11 vs 15 or 16), fewer interopercular odontodes (5-8 vs 10 or 11), fewer anal-fin rays (total of $8 v s 9$ ), and fewer pelvic-fin rays (total of 4 or 5 vs 6).
Description. Morphometric data in Table 1. Dorsal profile of body convex from tip of snout to midline of trunk and slightly convex from that point to base of caudal fin. Ventral body profile convex from mouth to point at vertical through pectoral-fin origin; slightly convex from that point to origin of caudal peduncle; slightly convex from origin of caudal peduncle to caudal-fin origin. Caudal peduncle strongly compressed. Urogenital opening at vertical posterior to dorsal-fin origin. Head triangular in dorsal view, depressed, broader than long. Eye elliptical, laterally positioned on head. Anterior profile of snout rounded. Mouth subterminal and crescent-shaped. Nasal barbel reaching posterior margin of eye. Maxillary barbel extending to posterior border of interopercular patch of odontodes. Rictal barbel reaching middle of interopercular patch of odontodes. Chin region with two finger-like projections. Teeth conical, three on premaxilla, irregularly arranged in a single row; four on dentary arranged in a single row. Opercular and interopercular patches of odontodes elliptical; opercular odontodes 8-11; interopercular odontodes 5-8. Opercular and interopercular odontodes 
Table 1. Morphometric data of Ammoglanis obliquus sp. nov.

\begin{tabular}{lccccc}
\hline & Holotype & Minimum & Maximum & Mean & SD \\
\hline Standard Length & 14.1 & 12.9 & 15.5 & 14.0 & \\
Body Depth & 10.6 & 10.6 & 13.7 & 11.9 & 0.7 \\
Caudal-Peduncle Depth & 8.5 & 8.3 & 9.8 & 9.0 & 0.5 \\
Body Width & 8.5 & 7.6 & 9.8 & 8.9 & 0.7 \\
Caudal-Peduncle Width & 1.4 & 0.7 & 2.6 & 1.0 & 0.6 \\
Predorsal Length & 63.8 & 60.7 & 65.5 & 63.1 & 1.3 \\
Preanal Length & 68.8 & 68.8 & 74.4 & 70.8 & 1.7 \\
Prepelvic Length & 51.1 & 50.4 & 52.6 & 51.4 & 0.6 \\
Dorsal-fin base length & 5.7 & 3.9 & 6.5 & 5.6 & 0.7 \\
Anal-fin base length & 5.0 & 3.1 & 5.8 & 4.8 & 0.8 \\
Pectoral-fin length & 8.5 & 7.0 & 9.8 & 8.7 & 0.7 \\
First pectoral-fin ray length & 25.5 & 18.6 & 28.7 & 22.5 & 3.4 \\
Pelvic-fin length & 7.8 & 7.0 & 9.8 & 8.7 & 0.8 \\
\hline Head Length & 12.8 & 11.9 & 13.5 & 12.9 & 0.4 \\
Head Depth & 55.6 & 55.6 & 70.6 & 61.6 & 4.9 \\
Head Width & 100.0 & 100.0 & 105.9 & 102.0 & 2.8 \\
Snout Length & 44.4 & 37.5 & 50.0 & 43.8 & 4.3 \\
Interorbital Width & 27.8 & 25.0 & 33.3 & 28.3 & 2.5 \\
Eye Diameter & 16.7 & 16.7 & 23.5 & 19.7 & 2.7 \\
Mouth Width & 44.4 & 43.8 & 55.0 & 47.4 & 4.0 \\
Interopercular Patch Length & 22.2 & 18.8 & 27.8 & 22.7 & 2.3 \\
Opercular Patch Length & 22.2 & 15.0 & 23.5 & 20.8 & 2.7 \\
\hline
\end{tabular}

conical, tips of odontodes curved dorsomedially. Cranial fontanel wide, lozenge-shaped, delimited anteriorly by mesethmoid and frontal and posteriorly by sphenotic and supraoccipital.

Dorsal fin subtriangular; dorsal-fin rays ii,6. Dorsal-fin first pterygiophore posterior to neural spines of $18^{\text {th }}$ vertebra; tip of its last pterygiophore immediately anterior to neural spine of $21^{\text {th }}$ vertebra. Seven dorsal-fin pterygiophores. Anal fin subtriangular, its origin at vertical posterior to dorsal-fin base; anal-fin rays ii,5 plus one rudimentary ray on fin origin. Anal-fin first pterygiophore posterior to neural spines of $20^{\text {th }}$ or $21^{\text {st }}$ vertebra; tip of its last pterygiophore immediately anterior to neural spine of $24^{\text {th }}$ vertebra. Six anal-fin pterygiophores. Origin of anal fin in a vertical through origin of first or second branched dorsal-fin ray. Caudal fin subtruncate; principal caudal-fin rays ii,4+4,ii. Dorsal procurrent caudal-fin rays 6 or 7; ventral procurrent caudal-fin rays 7. Both caudal-fin lobes with four branched rays. Middle rays of caudal fin branched once. Parhypural and hypurals 1 and 2 fused and bearing six rays. Hypurals 3, 4, and 5 fused to each other, bearing six rays. Neural arch of compound centrum incomplete. Uroneural thin and elongate. Pelvic fin slightly pointed, its tip reaching vertical through origin of dorsal-fin base, pelvic-fin bases medially separated by interspace nearly equal to pelvic-fin base width; pelvic-fin rays i,2,i (2) or i,2,ii (2). Pelvic-fin origin in vertical through base of hemal spine of $11^{\text {th }}$ or $12^{\text {th }}$ vertebra. Pectoral fin approximately subtriangular in dorsal view, first pectoral-fin ray terminating in long filament reaching about $50 \%$ of pectoral-fin length without filament; pectoral-fin rays i,5. Vertebrae 34 or 35; ribs two.

Mesethmoidal region and adjacent structures (Fig. 5). Anterior margin of mesethmoid slightly concave. Antorbital scythe-shaped in dorsal view; sesamoid supraorbital absent. Premaxilla without prominent lateral process, but with distal portion pointed. Maxilla slender, twice longer than premaxilla. Autopalatine approximate-

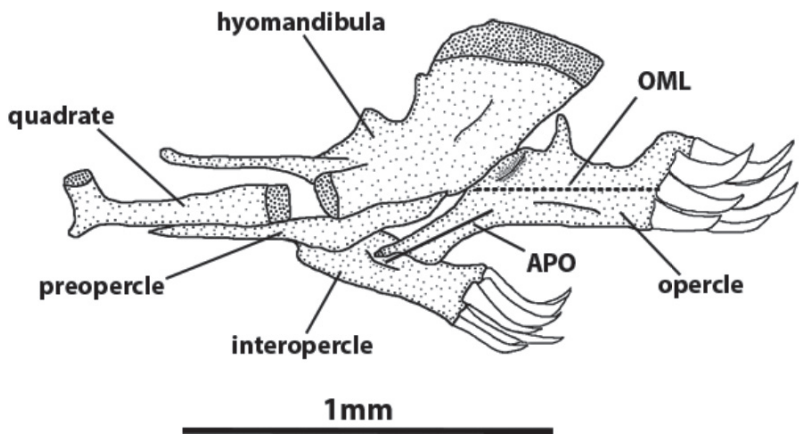

Figure 3. Ammoglanis obliquus, UFRJ 12478, $13.2 \mathrm{~mm} \mathrm{SL}$; lateral view of the left suspensorium and opercular apparatus. APO - anteroventral process of opercle length; OML - opercular main axis length.

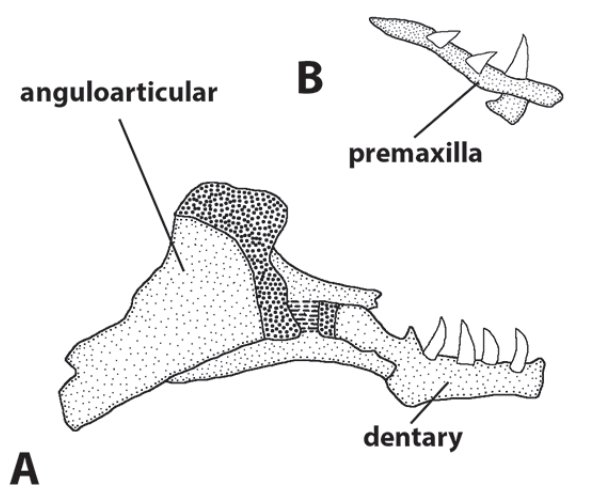

$500 \mu \mathrm{m}$

Figure 4. Ammoglanis obliquus, UFRJ 12478, $13.2 \mathrm{~mm}$ SL. A. Ventral view of the left premaxilla; B. Medial view of left lower jaw.

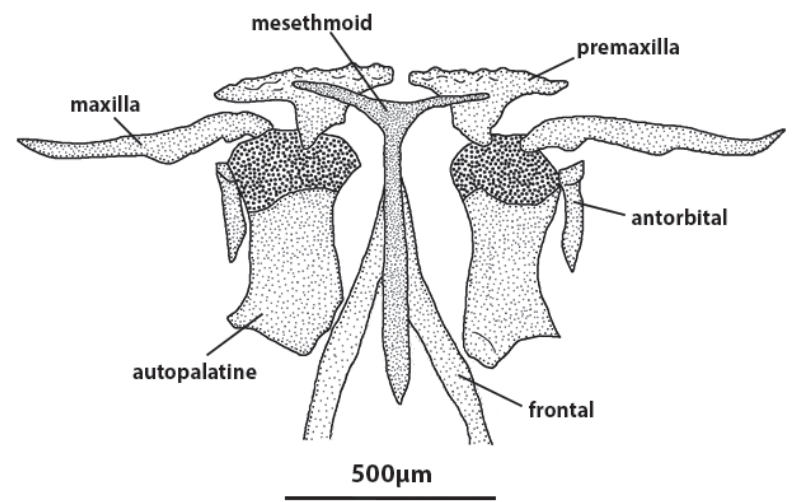

Figure 5. Ammoglanis obliquus, UFRJ 12478, 13.2mm SL; dorsal view of mesethmoidal region and associated structures.

ly rectangular; latero-posterior process of autopalatine short; cartilaginous head of autopalatine long, about onethird of autopalatine; anterior autopalatine ossification absent.

Suspensorium and opercular apparatus (Fig. 3). Metapterygoid absent. Quadrate long and slender, its length about $75 \%$ length of hyomandibula without anterior process, its depth about $30 \%$ to quadrate total length; postero-dorsal process of quadrate absent. Hyomandib- 
ula with narrow, pointed anteriorly directed process, its length about $67 \%$ hyomandibula longitudinal length excluding process, its tip anteriorly reaching vertical through anterior half of quadrate. Interopercle compact, without anterior projection. Opercle robust, its greatest depth about $40 \%$ of its length, excluding processes and odontodes patch; anteroventral process of opercle long, its length about $75 \%$ length of opercle main axis excluding odontode patch.

Colouration in life. Head integument and musculature transparent, pinkish colouration from blood vessels visible by transparency. Dorsal surface of head and dorso-lateral surface of body with dark chromatophores scattered over snout and distal portion of premaxilla, internal pigmentation from brain case visible mainly by transparency. Head ventral and ventro-lateral surfaces with few dark chromatophores, mostly forming small patches. Eyes black. Barbels transparent with few minute internal chromatophores over support cartilage. Trunk transparent with lipid grains visible along visceral cavity and dorsal midline. Pinkish colouration from blood vessels visible by transparency. Dorsal surface with dark chromatophores grouped in regular intervals, forming seven poorly-defined blotches. Trunk lateral surface with scattered dark chromatophores arranged along midline, highly concentrated near caudal fin base, forming banded pattern. Trunk ventro-lateral surface with grouped inner dark chromatophores, forming seven diagonal bands. Vertebral column with dark colouration visible by transparency, arranged in regular intervals matching dorsal and ventro-lateral chromatophores and composing lateral portion of banded pattern. Fins hyaline, with few dark chromatophores scattered on caudal fin and at base of anal fin.

Colour in alcohol. Ground colouration of trunk and head whitish, with few minute dark chromatophores on dorsum, flank, and head. Chromatophores concentrated forming a vertical band on base of caudal fin and in middle of caudal peduncle. Melanophores concentrated at regular intervals along dorsum, forming eight bands in dorsal view. Dark chromatophores in head concentrated in base of opercular patch of odontodes and in brain and snout area. Fins hyaline.

Distribution. Known only from its type locality in Rio Preto da Eva drainage, Amazonas river basin, northern Brazil.

Etymology. From the Latin obliquus, meaning oblique, referring to the conspicuous diagonal banded colouration pattern of living specimens.

Ecological notes. This species is known only from a small clearwater tributary of Preto da Eva river, which is a left margin tributary of the Amazonas river. Individuals were found associated with a sand-bank lying on the centre of an artificial widening of the main course, next to a road. The stream course margins were lined by gallery rainforest, and the water column was about $1 \mathrm{~m}$ deep with a weak current. The sand-bank was composed of coarse, yellow sand and with sparse patches of small banks of macrophytes. Capture was accomplished by scooping of

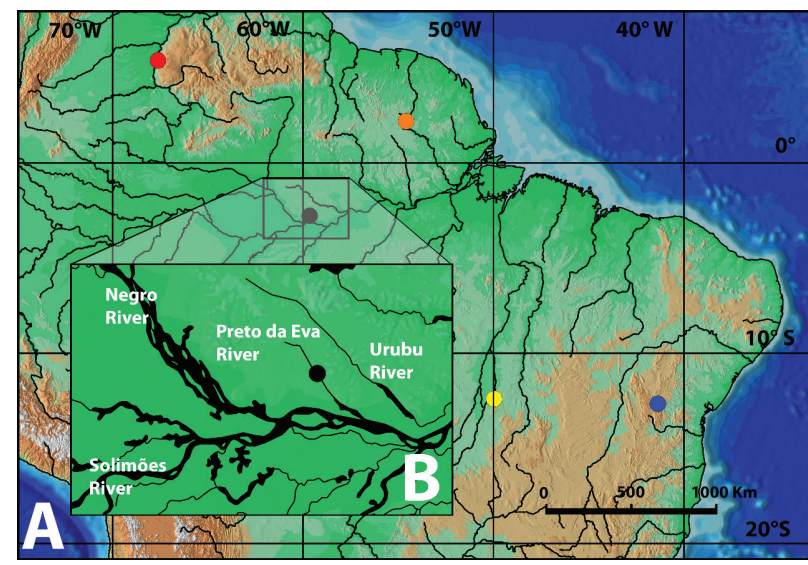

Figure 6. Geographic distribution of species of Ammoglanis. Red circle - A. pulex; black circle - A. obliquus; orange circle A. amapaensis; yellow circle $-A$. diaphanous; blue circle $-A$. multidentatus.

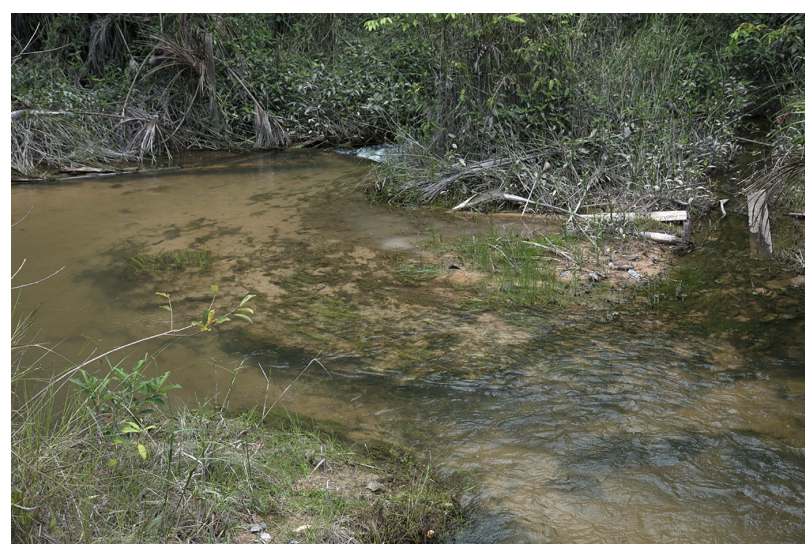

Figure 7. Habitat of Ammoglanis obliquus.

the superficial layer of sand with fine hand-nets. Specimens of Potamoglanis Henschel, Mattos, Katz \& Costa, 2018 and Ammocryptocharax Weitzman \& Kanazawa, 1976 were frequently captured together with Ammoglanis obliquus. This area as a whole is under high deforestation pressure due to local human occupation.

\section{Discussion}

Ammoglanis obliquus is allocated to the genus Ammoglanis by the presence of a long and slender quadrate, its greatest length about $75 \%$ of the length of the hyomandibula excluding the anterior process and its greatest depth about $30 \%$ of the quadrate total length (Fig. 3). This character state was first proposed by Costa (1994) to diagnose the genus and was confirmed to occur in all other species of Ammmoglanis, as stated by de Pinna and Winemiller (2000), Mattos et al. (2008), and Costa et al. (2019). Ammoglanis obliquus is probably more closely related to $A$. pulex and A. amapaensis than to its other congeners. Ammoglanis pulex and A. amapaensis have been considered closely related taxa due to their unique oral, antorbital, and autopalatine morphology (Mattos et al. 2008; Costa et al. 2019a). As seen in A. pulex and A. amapaensis, 
A. obliquus also exhibits a subventral mouth, a scytheshaped antorbital with an anterior facet (Fig. 5; de Pinna and Winemiller 2000: fig. 6; Mattos et al. 2008: fig. 5), and a compact autopalatine with the lateral margin slightly concave and the medial margin slightly convex, bearing a small posterolateral process (Fig. 5; de Pinna and Winemiller 2000: fig. 6; Mattos et al. 2008: fig. 5). According to Costa et al. (2019a), the autopalatine morphology recorded for A. pulex and A. amapaensis is apomorphic and indicates a close relationship between these two species. Therefore, because $A$. obliquus has the same autopalatine shape, we consider this character state synapomorphic for A. obliquus, A. pulex, and A. amapaensis. Ammoglanis obliquus and A. pulex share some unique character states indicating that they are sister taxa: absence of the metapterygoid, a condition unique among sarcoglanidines (Fig. 3; de Pinna and Winemiller: fig. 5), and a similar colour pattern, with eight poorly-defined bands of chromatophores visible in dorsal view and dark chromatophores in the interior of the body forming a banded pattern (Figs 1A, B, 2).

\section{Acknowledgements}

Thanks are due to J.L.O. Mattos for laboratorial assistance and to P. Vilardo for helping to edit images. A. Katz gently helped photographing fixed specimens. E. Henschel was funded by National Geographic Society (Early Carreer Grant Number EC-316R-18) and CNPq (Conselho Nacional de Desenvolvimento Científico e Tecnológico, Ministério de Ciência e Tecnologia). This study is part of E. Henschel's PhD thesis. This study was also supported by Coordenação de Aperfeiçoamento de Pessoal de Nível Superior (CAPES, Finance Code 001) through Programa de Pós-Graduação em Genética/UFRJ.

\section{References}

Aedriens D, Baskin JN, Coppens H (2010) Evolutionary morphology of trichomycterid catfishes: about hanging on and digging in. In: Nelson JS, Wilson MVH (Eds) Origin and Phylogenetic Interrelationships of Teleosts. Verlag Dr. Friedrich Pfeil, Munchen, 337-362.

Close B, Banister K, Baumans V, Bernoth E-M, Bromage N, Bunyan J, Erhardt W, Flecknell P, Gregory N, Hackbarth H, Morton D, Warwick C (1996) Recommendations for euthanasia of experimental animals: Part 1. Laboratory Animals 30: 293-316. https://doi. org/10.1258/002367796780739871

Close B, Banister K, Baumans V, Bernoth E-M, Bromage N, Bunyan J, Erhardt W, Flecknell P, Gregory N, Hackbarth H, Morton D, Warwick C (1997) Recommendations for euthanasia of experimental animals: part 2. Laboratory Animals 31: 1-32. https://doi. org/10.1258/002367797780600297

Costa WJEM (1992) Description de huit nouvelles espèces du genre Trichomycterus (Siluriformes: Trichomycteridae), du Brésil oriental. Revue Française d'Aquariologie 18: 101-110.
Costa WJEM (1994) A new genus and species of Sarcoglanidinae (Siluriformes: Trichomycteridae) from the Araguaia basin, central Brazil, with notes on subfamilial phylogeny. Ichthyological Exploration of Freshwaters 5: 207-216.

Costa WJEM, Mattos JLO, Santos ACA (2019) Ammoglanis multidentatus, a new miniature sand-dwelling sarcoglanidine catfish with unique osteological features from northeastern Brazil (Siluriformes: Trichomycteridae). Vertebrate Zoology 70(1): 61-67. https://oi. org/10.26049/VZ70-1-2020-04

D'agosta FCP, de Pinna MCC (2019) The fishes of the Amazon: distribution and biogeographical patterns, with a comprehensive list of species. Bulletin of the American Museum of Natural History 431: 1-163. https://doi.org/10.1206/0003-0090.431.1.1

Costa WJEM, Henschel E, Katz AM (2020) Multigene phylogeny reveals convergent evolution in small interstitial catfishes from the Amazon and Atlantic forests (Siluriformes: Trichomycteridae). Zoologica Scripta 49(2): 159-173. https://doi.org/10.1111/ zsc. 12403

Datovo A, Bockmann FA (2010) Dorsolateral head muscles of the catfish families Nematogenyidae and Trichomycteridae (Siluriformes: Loricarioidei): comparative anatomy and phylogenetic analysis. Neotropical Ichthyology 8: 193-246. https://doi.org/10.1590/ S1679-62252010000200001

Leary S, Underwood W, Anthony R, Cartner S, Corey D, Grandin T (2013) AVMA guidelines for the euthanasia of animals: 2013 edition. http://works.bepress.com/cheryl_greenacre/14

Myers GS, Weitzman SH (1966) Two remarkable new trichomycterid catfishes from the Amazon basin in Brazil and Colombia. Journal of Zoology 149: 277-287. https://doi.org/10.1111/j.1469-7998.1966. tb04049.x

de Pinna MCC (1989) A new sarcoglanidine catfish, phylogeny of its subfamily, and an appraisal of the phyletic status of the Trichomycterinae (Teleostei, Trichomycteridae). American Museum Novitates 2950: 1-39. http://hdl.handle.net/2246/5105

de Pinna MCC, Starnes WC (1990) A new genus and species of Sarcoglanidinae from the Río Mamoré, Amazonas Basin, with comments on subfamilial phylogeny (Teleostei, Trichomycteridae). Journal of Zoology 222: 75-88. https://doi.org/10.1111/j.1469-7998.1990. tb04030.x

de Pinna MCC, Winemiller KO (2000) A new species of Ammoglanis (Siluriformes: Trichomycteridae) from Venezuela. Ichthyological Exploration of Freshwaters 11: 255-264.

Reis RE, Albert JS, Di Dario F, Mincarone MM, Petry P, Rocha LA (2016) Fish biodiversity and conservation in South America. Journal of Fish Biology 89(1): 12-47. https://doi.org/10.1111/jfb.13016

Taylor WR, Van Dyke GC (1985) Revised procedures for staining and clearing small fishes and other vertebrates for bone and cartilage study. Cybium 9: 107-109.

Zuanon J, Bockmann FA, Sazima I (2006) A remarkable sand-dwelling fish assemblage from central Amazonia, with comments on the evolution of psammophily in South American freshwater fishes. Neotropical Ichthyology 4(1): 107-118. https://doi.org/10.1590/S167962252006000100012

Zuanon J, Sazima I (2004) Natural history of Stauroglanis gouldingi (Siluriformes: Trichomyteridae), a miniature sand-dwelling candiru from central Amazonian streamlets. Ichthyological Exploration of Freshwaters 15: 201-208. 